УДК 355.233.1:355.457(477)

Сергій Білявець, кандидат педагогічних наук, доиент кафедри оперативного мистецтва факультетукерівних кадрів Наиіональна академія Державної прикордонної служби України імені Богдана Хмельнииького

\title{
КОНЦЕПЦІЯ ТА ПЕДАГОГІЧНІ РЕЗЕРВИ НАВЧАННЯ МАЙБУТНІХ ОФІЦЕРІВ- ПРИКОРДОННИКІВ ВІЙСЬКОВО-СПЕЦАЛЬНИХ ДИСЦИПЛІН ЩОДО ФОРМУВАННЯ ПРОФЕСІЙНОЇ КОМПЕТЕНТНОСТІ
}

У статті окреслено основні положення концепиії та педагогічні резерви освітнього процесу щзодо формування у майбутніх офіцерів-прикордонників професійної компетентності у процесі навчання військово-спеціальних дисциплін. Охарактеризовано методичну систему формування професійної компетентності у процесі навчання військово-спеціальних дисииплін. Ця система містить низку компонентів, серед яких основними є підсистема мети $i$ завдань, методів $і$ форм організації навчання військово-спеціальних дисциплін, змісту навчання та підсистему його корекції, підсистему діяльності курсанта, контролю результатів формування професійної компетентності майбутніх офіцерівприкордонників, підсистему засобів навчання, а також підсистему результатів.

Ключові слова: офіцер-прикордонник, професійна компетентність, методична система, курсанти, військово-спеціальні дисципліни.

Jim. 5.

Serhiy Bilyavets, Ph.D.(Pedagogy), Associate Professor of the Operative Art Department of Leading Staff Faculty

National Bohdan Khmelnytskiy Academy of the State Border Guard Service of Ukraine

\section{CONCEPT AND PEDAGOGICAL RESERVES OF TEACHING THE FUTURE BORDER GUARD OFFICERS IN MILITARY SPECIAL DISCIPLINES REGARDING THE FORMATION OF PROFESSIONAL COMPETENCE}

The article outlines the main provisions of the concept and pedagogical reserves of the educational process regarding the formation of professional competence of future border guard officers in the process of studying the military special disciplines. It is noted that the Border Guard Service puts forward a number of specific requirements of the personality of the border guard officer, provides for an appropriate level of the formation of their professional competence. This is the reason for considering the proper organization of the educational process in a higher military educational establishment in order to form the professional competence of the future defenders of the border. The problem of forming the professional competence of the officers of the border guard agency has repeatedly been the subject matter of scientific researches. However, at present there has not been developed an appropriate methodological system for the formation of professional competence of future border guard officers in the process of studying the process of training in military special disciplines.

The author gives the characteristics of the methodological system of forming the professional competence in the process of studying military special disciplines. This system contains a number of components, among which the main are the following: the subsystem of goals and tasks, the methods and forms of organization of studying the military special disciplines, the content of training and the subsystem of its correction, the subsystem of the cadet's activity, the control of the results of the formation of professional competence of future border guard officers, the subsystem of training facilities, as well as the subsystem of results.

Among the pedagogical reserves of the educational process regarding the formation of professional competence of future border guard officers in the process of studying the military special disciplines, it should be pointed out the need for a holistic impact on all the components of the system of forming the professional competence of future border guard officers in the process of studying the military special disciplines. The methodological system should facilitate the improvement of the quality of training the officers for the border guard department; ensure the mutual responsibility of the subjects of the educational process for the final results of training of border officers.

Keywords: a border guard officer, professional competence, a methodical system, cadets, military special disciplines.

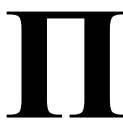

остановка проблеми. Державна прикордонна служба України виконуе надзвичайно важливе завдання охорону державного кордону. Центральною ланкою прикордонної діяльності є офіцер- прикордонник, який виконує оперативнослужбову діяльність 3 охорони державного кордону. Він є керівником і організатором безпосередніх дій підпорядкованого персоналу, посадовою особою, яка якнайповніше відповідає 
КОНЦЕПЦІЯ ТА ПЕДАГОГІЧНІ РЕЗЕРВИ НАВЧАННЯ МАЙБУТНІХ ОФІЦЕРІВПРИКОРДОННИКІВ ВІЙСЬКОВО-СПЕЦІАЛЬНИХ ДИСЦИПЛІН ЩОДО ФОРМУВАННЯ ПРОФЕСІЙНОЇ КОМПЕТЕНТНОСТІ

за результати прикордонної діяльності, спрямованої на припинення порушень законодавства 3 прикордонних питань. Прикордонна служба висуває низку специфічних вимог до особистості прикордонника, передбачає належний рівень сформованості його професійної компетентності. Саме цим обумовлена необхідність розгляду питання щодо належної організації освітнього процесу у вищому військовому навчальному закладі (ВВН3) з метою формування професійної компетентності майбутніх захисників кордону.

Аналіз останніх досліджень і публікацій. Проблема формування професійної компетентності офіцерів прикордонного відомства неодноразово була предметом наукових досліджень. Серед тих, що виконані в останні роки, заслуговують на увагу праці В. Веретільника (розвиток військовоспеціальної компетентності офіцерівприкордонників) [1], О. Діденка (особливості змісту та сутність професійної компетентності офіцера-прикордонника) [2, 263 - 264], Н. Логінової (формування професійно-правової компетентності майбугніх офіцерів-прикордонників) [3], А. Машталера (розвиток професійної компетентності офіцерів-прикордонників у системі підвищення кваліфікації засобами дистанційного навчання) [4], О. Торічного (формування професійної компетентності майбутніх офіцерівприкордонників засобами проектної діяльності) [5] та інших. Певний інтерес представляють також праці, у яких проаналізовано зміст професійної компетентності фахівців правоохоронних органів України та військових формувань. Це праці С. Каплуна, В. Костенка, О. Маслія, Т. Ткаченка, Т. Трегубенко (формування професійної компетентності майбутніх дільничних інспекторів міліції у процесі фахової підготовки), Г. Яворської та ін. Проте на сьогодні не розроблено відповідної методичної системи формування професійної компетентності майбутніх офіцерів-прикордонників упроцесі навчання військово-спеціальних дисциплін.

Метою статті $\epsilon$ характеристика концепції формування професійної компетентності майбутніх офіцерів-прикордонників у процесі навчання військово-спеціальних дисциплін та педагогічних резервів освітнього процесу ВВНЗ.

Виклад основного матеріалу дослідження. Проведене дослідження дозволило зробити висновок, що освітній процес ВВНЗ має великі резерви i можливості для покращення ефективності методичної системи формування професійної компетентності майбутніх офіцерівприкордонників під час навчання військовоспеціальних дисциплін. 3 цією метою науково- педагогічному складу, командирам курсантських підрозділів та офіцерам по роботі з персоналом важливо дотримуватись рекомендацій, які розроблено на основі проведеного дослідження.

3'ясовано, що одним з визначальних напрямів підвищення якості професійної підготовки майбутніх офіцерів-прикордонників $є$ розвиток системи відомчої освіти, а також основних функціональних компонентів методичної системи формування професійної компетентності майбутніх офіцерів-прикордонників у процесі навчання військово-спеціальних дисциплін, досягнення на цій основі нового більш високого рівня освітнього процесу загалом. Методична система формування професійної компетентності майбутніх офіцерів-прикордонників у процесі навчання військово-спеціальних дисциплін $\epsilon$ цілісною та багатокомпонентною, iї утворюють інтегровані взаємопов'язані системотвірні зв' язки між такими основними елементами, як: курсанти, викладачі, мета навчання військово-спеціальних дисциплін, їх зміст, методи, засоби й організаційні форми навчання, а також прийоми діагностики професійної компетентності.

Для формування професійної компетентності майбутніх офіцерів-прикордонників у процесі навчання військово-спеціальних дисциплін важливе значення має вплив на всі складові цієї системи, зокрема підсистему цілей та завдань, змістову складову, підсистему педагогічної діяльності, підсистему діяльності курсантів, підсистему методів навчання, підсистему засобів та форм навчання, а також підсистему контролю результатів у поєднанні з самоконтролем

Якнайкращим чином відповідає вимогам щодо визначення цілей навчання діяльнісний підхід. За діяльнісного підходу спосіб постановки цілей у навчанні полягає в тому, що цілі навчання формуються через результати навчання, виражені в діях курсантів. За такої постановки мети знання визначає зміст навчального матеріалу, а вміння в загальному вигляді характеризує дії, які повинен виконувати курсант у результаті освоєння цього матеріалу. Визначити ціль навчання 3 певної військово-спеціальної дисципліни - значить виявити і сформувати систему умінь, якими повинні оволодіти курсанти. Фактично мета навчання дисципліни або тактична мета навчання являє собою опис видів діяльності, які формуються в процесі вивчення, перелік професійних умінь, необхідних офіцерові-прикордоннику для вирішення його професійних завдань, а також усіх тих особистісних характеристик, які слід сформувати в процесі засвоєння відповідної військово-спеціальної дисципліни. 


\section{КОНЦЕПЦІЯ ТА ПЕДАГОГІЧНІ РЕЗЕРВИ НАВЧАННЯ МАЙБУТНІХ ОФІЦЕРІВ- ПРИКОРДОННИКІВ ВІЙСЬКОВО-СПЕЦІАЛЬНИХ ДИСЦИПЛІН ЩОДО ФОРМУВАННЯ ПРОФЕСІЙНОЇ КОМПЕТЕНТНОСТІ}

Для формування професійної компетентності майбутніх офіцерів-прикордонників у процесі навчання військово-спеціальних дисциплін необхідно передусім використовувати модель випускника ВВНЗ, основою якої є кваліфікаційна характеристика або освітньо-професійна програма. Насамперед слід брати до уваги вибір і опис типових завдань (задач), які курсант майбутній офіцер-прикордонник виконуватиме у майбутній професійній діяльності. Опис цих завдань у певній послідовності дозволяє будувати поступовість або ієрархію формування цілей вищої освіти.

Крім того, потрібно брати до уваги, що мету краще формулювати так, щоб вона вказувала на заплановані результати навчання - сукупність компетентностей, які виражають знання, розуміння, уміння, цінності, інші особисті якості, що їх набув курсант після завершення освітньої програми, або її окремого компонента. У цьому полягає зв'язок підсистеми мети і завдань формування професійної компетентності майбутніх офіцерів-прикордонників у процесі навчання військово-спеціальних дисциплін 3 підсистемою результатів формування професійної компетентності майбутніх офіцерівприкордонників.

При цьому результати навчання майбутніх офіцерів доцільно прив'язати не лише до певного циклу вищої освіти, а до кожного курсу навчання. Це передбачатиме, що метою навчання у ВНЗ ДПСУ є підготовка офіцера-прикордонника, здатного вирішувати складні стандартні та нестандартні завдання, професійні й проблемні ситуації, які виникають перед прикордонним підрозділом у процесі охорони державного кордону. Слід визначити стратегічні, тактичні та оперативні цілі, визначивши їх у формі переліку професійних умінь, з урахуванням специфіки професійної діяльності офіцера-прикордонника, ієрархії посадових обов'язків і функцій, професійних завдань (задач), що їх виконуватимуть офіцери-прикордонники у майбутній професійній діяльності, а також поетапного їх вирішення на кожному курсі навчання - формування професійної компетентності молодшого інспектора прикордонної служби (1 курс), інспектора прикордонної служби (2 курс), начальника відділення інспекторів прикордонної служби (3 курс) та начальника відділу прикордонної служби (4 курс).

У підсистемі методів навчання військовоспеціальних дисциплін важливо брати до увагу, що для того щоб вибрати відповідні методи, викладач повинен знати цілі навчання, оскільки методологія, по суті, пов' язана із цілями навчання. Навчання потрібно здійснювати цілеспрямовано, 3 орієнтацією на досягнення конкретних цілей, на основі взаємодії між викладачами і курсантами. Вибір методів навчання має грунтуватися на таких трьох категоріях цілей навчання: а) знання й розуміння, б) ціннісні орієнтації, ставлення й досвід, і в) уміння, навички й компетенції.

3 огляду на важливість побудови процесу викладання-навчання навколо курсантів, їхніх знань, ціннісних орієнтацій, ціннісного ставлення, умінь, навичок i досвіду, важливо використовувати декілька груп методів. Насамперед це методи навчання, орієнтовані на курсантів - індивідуальна робота, рольові ігри, робота в групі/ робота в невеликій групі, проектна робота в невеликих групах, комунікативний метод, навчання в команді, робота в команді, обмін досвідом, практичні заняття, аналіз конкретних випадків (кейси), постановочна сценка, читання, есе, оповідання, змодельована ситуація, навчальний щоденник, навчальний журнал або книга щоденних записів, оцінка портфеля робіт, дистанційне навчання, Інтернет, проектна робота або проектне навчання.

Методи навчання, орієнтовані на викладача (викладання) - це викладання в аудиторії/ підготовка в аудиторії, демонстрація, лекційне викладання, лекції з діалогами (розмова), семінар. Серед інтерактивних методів навчання, орієнтованих на курсанта й викладача, можна використовувати такі: обговорення в аудиторії й групі, активне обговорення, інтерактивні демонстрації, “мозковий штурм”, наставництво, тьюторінг, навчання на робочому місці, стажування, екскурсія.

При цьому слід забезпечити орієнтацією на досягнення конкретних цілей навчання на основі взаємодії між викладачами і курсантами, а також підвищення мотивації майбутніх офіцерів і розуміння ними цінності навчання на основі залучення їх до вибору методів навчання. При виборі методів навчання слід враховувати, що курсанта слід розглядати не лише як об'єкта, а й як суб'єкта процесу викладання-навчання. 3 погляду мотивації до пізнавальної активності важливо, що курсант повинен сам усвідомлювати цінність свого навчання. 3 урахуванням цього 3 міркувань підвищення мотивації курсантів і розуміння ними цінності навчання слід залучати їх до процесу вибору.

У підсистемі результатів формування професійної компетентності майбутніх офіцерівприкордонників важливо враховувати, що 
КОНЦЕПЦІЯ ТА ПЕДАГОГІЧНІ РЕЗЕРВИ НАВЧАННЯ МАЙБУТНІХ ОФІЦЕРІВПРИКОРДОННИКІВ ВІЙСЬКОВО-СПЕЦІАЛЬНИХ ДИСЦИПЛІН ЩОДО ФОРМУВАННЯ ПРОФЕСІЙНОЇ КОМПЕТЕНТНОСТІ

авторитарна модель освіти другої половини $\mathrm{XX} \mathrm{ст.} \mathrm{обмежувалася} \mathrm{вихованням} \mathrm{зовнішньої}$ дисциплінарної відповідальності: індивід повинен був виконати обов'язок перед суспільством. Сьогодні важливо відходити від одностороннього педагогічного впливу, а орієнтуватися на принцип спільної ціннісної діяльності, що передбачає створення більш коректних педагогічних ситуацій розвитку. Курсант має бути не тільки об'єктом зовнішніх, а насамперед суб'єктом освітніх змін, співучасником педагогічного процесу, творчою особистістю.

Важливо звертати увагу на розвиток внутрішньої форми відповідальності за результати навчальної діяльності, що пов'язана 3 почуттям обов'язку, саморегуляцією власних дій, професійною спрямованістю курсанта, його активною життєвою позицією, здоровим способом життя, здатністю та готовністю до самореалізації та самовдосконалення. Відповідальність у такому випадку перетворює зовнішній обов'язок у внутрішню потребу, що супроводжується переходом зовнішнього контролю до самоконтролю особистості.

У підсистемі діяльності науково-педагогічного складу ВВНЗ важливе значення має урахування індивідуальної своєрідності розвитку особистості курсантів 3 вимогами державного стандарту вищої освіти щодо сформованості їх професійної компетентності. Йдеться про таку організацію навчального процесу, за якої вибір способів, прийомів, темпу навчання враховує індивідуальні відмінності курсантів, рівень розвитку їхніх здібностей до навчання.

Основою індивідуалізації професійної підготовки курсантів має бути принцип варіативності вибору змісту і форм діяльності 3 вивчення військово-спеціальних дисциплін. Варіативний підхід у навчанні повинен передбачати різноманіття, рівневість, диференційованість вправ і завдань, можливість випереджального навчання, наступність форм навчання, а також варіативний вибір індивідуальної освітньої траєкторії.

Індивідуальну самостійну роботу слід здійснювати головним чином за допомогою диференційованих завдань, які враховують особливості курсантів. Для забезпечення варіативності навчання необхідно у рамках навчального процесу використовувати також індивідуальні додаткові завдання, диференційовану за характером самостійну роботу, завдання різного ступеня складності, індивідуальні графіки виконання навчального плану, навчальнодослідницькі завдання для курсантів. Важливе значення має також належна побудова навчального заняття, підбір дидактичного матеріалу.

У підсистемі змісту навчання військовоспеціальних дисциплін, що охоплює науково обгрунтований методичний та дидактичний навчальний матеріал, засвоєння якого забезпечує здобуття освіти й кваліфікації згідно з освітнім рівнем, слід здійснити комплекс заходів, необхідних для забезпечення підготовки офіцера прикордонника до виконання посад від молодшого інспектора прикордонної служби до начальника відділу прикордонної служби за таким алгоритмом: 1 курс навчання - підготовка молодшого інспектора прикордонної служби молодшого прикордонного наряду, підготовка командира відділення механізованого взводу; 2 курс навчання - підготовка інспектора прикордонної служби (старшого прикордонного наряду), підготовка командира механізованого взводу; 3 курс навчання - підготовка начальника відділення інспекторів прикордонної служби (старшого зміни прикордонних нарядів), підготовка командира роти; 4 курс навчання підготовка начальника відділу прикордонної служби III та IV категорії, підготовка командира батальйону.

На основі аналізу професійної діяльності офіцера-прикордонника слід окреслювати і стратегічну мету навчання, визначивши ті необхідні професійні вміння та якості, які слід сформувати в процесі навчання, Далі, на підставі стратегічної мети, потрібно складати програму професійної підготовки фахівця. Для визначення змісту навчання слід: 3'ясувати необхідну функціональну структуру професійної діяльності офіцера-прикордонника відповідно до рівня його кваліфікації; визначити структуру узагальненого об'єкта діяльності; виділити елементи сукупної структури професійної підготовки; поглиблено розкрити кожен $з$ цих елементів.

При підготовці офіцерів-прикордонників 3 курсу в курс дисципліни циклу професійної та практичної підготовки важливо розширювати у зв'язку зі зміною діапазону діяльності та розширенням об'єкта вивчення: відповідно від підготовки молодшого інспектора прикордонної служби до підготовки начальника відділу прикордонної служби III та IV категорій. Військово-спеціальні навчальні дисципліни необхідно розширювати за рахунок поглиблення їх теоретичних положень. Зокрема, на кожному курсі важливо враховувати, які вимоги кваліфікаційної характеристики може забезпечити та чи інша навчальна дисципліна. Призначення навчального предмета, або провідна функція 
предмета, повинні включати об’єкт вивчення і значення цього об’ єкта для професійної діяльності офіцера-прикордонника.

У підсистемі корекції змісту навчання військово-спеціальних дисциплін важливе значення має забезпечення науково обгрунтованого відбору і конструювання змісту підготовки на засадах моніторингу навчальних досягнень та експертної оцінки чинників, що впливають на зміст освіти та визначають пріоритети у підготовці офіцерів ДПСУ.

Процес коригування змісту, що пов'язаний 3 поточними та перспективними потребами суспільства, держави, ДПСУ, суспільнополітичною та соціально-економічною ситуацією в країні, державною стратегією розвитку освіти, державною стратегію розвитку ДПСУ, прогнозуванням розвитку військової справи, форм ведення бойових дій, озброєння, техніки та потреб суспільства, повинен передбачати змістовний аналіз відібраного нового навчального матеріалу 3 військово-спеціальних дисциплін, його структурування, побудову нових між- i внутрішньопредметних зв'язків. Тут важливо діяти не за ланцюжком "мета-завдання", а відразу оновлювати весь набір цілей навчального процесу: нові цілі навчальної дисципліни - цілі тем - цілі питань кожної теми. Після цього потрібно здійснити коригування всіх завдань.

У підсистемі форм організації навчання курсантів військово-спеціальних дисциплін слід звертати увагу на формування у курсантів професійної компетентності на різних формах занять із військово-спеціальних дисциплін, зокрема під час навчальних занять, самостійної роботи (самостійної підготовки) та практичної підготовки. Для формування у курсантів професійної компетентності в НАДПСУ важливе значення мають такі види навчальних занять, як лекція, семінарське, групове, лабораторне, практичне, індивідуальне заняття, групова вправа, тактико-стройове заняття, тактичне (тактико-спеціальне) навчання.

Для забезпечення професійної спрямованості у викладанні військово-спеціальних дисциплін важливе значення має впровадження в групові та практичні заняття елементів рольових ігор, комплексних практичних i контрольноперевірочних занять. У такому випадку використання елементів ділової гри дозволятиме практично відпрацьовувати весь комплекс питань 3 організації оперативно-службової діяльності та управління органами (підрозділами) під час виконання оперативно-службових завдань. Ділова гра може бути також засобом моделювання (дослідження) нових умов оперативно-службової діяльності, методом пошуку нових способів виконання оперативно-службових завдань.

У підсистемі діяльності курсанта для забезпечення моніторингу якості навчальної діяльності курсантів важливо звертати увагу на всі іiі складові, зокрема мотиваційний, операційний, інформаційний та регуляторний компоненти. Зокрема, щодо мотиваційної складової слід зазначити, що важливо, щоб курсанти усвідомили значущість своєї майбутньої професійної діяльності та були зацікавлені процесом і результатом свого професійного розвитку.

Організовуючи діяльність, у якій формуються мотиви, слід збагачувати зміст навчального матеріалу особистісно орієнтованим матеріалом; ознайомлювати курсантів 3 майбутньою професійною діяльністю та її суспільною значущістю, з вимогами, які вона висуває до знань і умінь; допомогти їм усвідомити ближні (безпосередні) й кінцеві (перспективні) цілі навчання; розвивати ціннісні орієнтації, що пов'язані з професійною діяльністю, прагнення до саморозвитку і самовдосконалення. Необхідно також виробляти у курсантів потреби і вміння самостійно працювати 3 літературою, навчатися самостійно; створювати умови для самопізнання, самовиховання, стимулювати прагнення до самовдосконалення; підтримувати допитливість й “пізнавальний” психологічний клімат у навчальній групі.

Для ефективного використання інформації у навчальному процесі необхідно, щоб вона відповідала певним вимогам. Вона повинна бути насамперед релевантною, тобто сприяти досягненню цілей навчання, а також доступною, тобто її слід подавати зрозумілою мовою, з використанням наочного способу надання інформації. Окрім того, важливо, щоб інформація була структурованою, що передбачає обробку інформації відповідно до під цілей та завдань. Для забезпечення оптимальної структури навчальної інформації важливо дотримуватись принципів мінімізації, об'єктивності, відповідності, логічності, підпорядкованості, зв'язку з практикою, а також відповідності структури навчальної інформації фізіологічним особливостям курсантів, закономірностям сприйняття, пам’яті, мислення.

У підсистемі контролю результатів формування професійної компетентності майбутніх офіцерів-прикордонників у процесі навчання військово-спеціальних дисциплін необхідне впровадження системи внутрішнього 
КОНЦЕПЦІЯ ТА ПЕДАГОГІЧНІ РЕЗЕРВИ НАВЧАННЯ МАЙБУТНІХ ОФІЦЕРІВПРИКОРДОННИКІВ ВІЙСЬКОВО-СПЕЦІАЛЬНИХ ДИСЦИПЛІН ЩОДО ФОРМУВАННЯ ПРОФЕСІЙНОЇ КОМПЕТЕНТНОСТІ

забезпечення якості освіти у ВНЗ ДПСУ. Система внугрішнього забезпечення якості освіти у ВНЗ має передбачати насамперед розроблення, затвердження, моніторинг і періодичний перегляд робочих програм військово-спеціальних дисциплін. Важливою складовою система внутрішнього забезпечення якості освіти у ВНЗ $€$ розроблення і впровадження системи оцінювання навчальних досягнень майбутніх офіцерівприкордонників. Система оцінювання навчальних досягнень майбугніх офіцерів-прикордонників має стосуватись усіх форм організації контролю за навчальною діяльністю: фронтальної, групової, індивідуальної, комбінованої та самоконтролю. Важливо використовувати потенціал усіх видів контролю.

У підсистемі засобів формування професійної компетентності майбугніх офіцерів-прикордонників слід розширити складові різних категорій засобів навчання, зокрема це стосується підручників, простих візуальних засобів, механічних візуальних засобів, аудіальних засобів, аудіовізуальних засобів та засобів, що автоматизують процеси навчання. Для забезпечення випереджального характер використання засобів викладання засобів навчання важливо орієнтуватись на новітні мультимедійні, імітаційні та інші засоби навчання, необхідні для набуття випускниками НАДПСУ актуальних для сучасних загроз і викликів на державному кордоні компетентностей. Загалом це дозволить значно підвищити ефективність навчання і в певних межах збільшити темп викладу навчального матеріалу, тобто інтенсифікувати процес навчання та формування професійної компетентності майбутніх офіцерівприкордонників.

Висновки. Серед педагогічних резервів освітнього процесу щодо формування професійної компетентності майбугніх офіцерів-прикордонників у процесі навчання військово-спеціальних дисциплін слід вказати на необхідність цілісного впливу на всі складові системи формування професійної компетентності майбутніх офіцерівприкордонників у процесі навчання військовоспеціальних дисциплін. Методична система має сприяти покращенню якості підготовки офіцерів для прикордонного відомства, забезпечити взаємну відповідальність суб' єктів освітнього процесу за кінцеві результати навчання офіцерівприкордонників.

Перспективами подальших наукових розвідок $є$ визначення передумов розвитку професійної компетентності офіцерівприкордонників у системі підвищення кваліфікації.

\section{ЛІТЕРАТУРА}

1. Веретільник В. В. Обтрунтування педагогічних умов розвитку військово-спеціальної компетентності офіцерів-прикордонників у прочесі магістерськоӥ підготовки / В. В. Веретільник, О. В. Діденко // Науковий журнал "ScienceRise: Pedagogical Education”- 2017. - № 2(10). - C. 46-50.

2.Діденко О. В. Професійна компетентність офічера-прикордонника: сутність поняття / О. В. Діденко // Освітньо-наукове забезпечення діяльності правоохоронних органів $і$ військових формувань України: тези VIII Всеукраїнськоі науково-практичної конференції Хмельницький: Видавниитво НАДПСУ, 2015. - 636 с., С. 263-264.

3. Логінова Н. М. Формування професійноправової компетентності майбутніх офіцерівприкордонників: автореф. дис. на здобуття наук. ступеня канд. пед. наук: 13.00.04 / Логінова Наталія Миколаївна; Нац. акад. Держ. прикордон. служби Украйни ім. Б. Хмельницького. -Хмельницький, 2011. $-20 \mathrm{c}$.

4. Машталер А. М. Розвиток професійної компетентності офіиерів-прикордонників у системі підвищення кваліфікачії засобами дистанційного навчання: автореферат дис. на здобуття наук. ступеня канд. пед. наук: спец. 13.00.04 / А. М. Машталер; Наи. акад. Держ. прикордон. служби України ім. Б. Хмельницького. Хмельницький, 2016. - 16 с.

5. Торічний О. В. Формування професійної компетентності майбутніх офіџерів-прикордонників засобами проектної діяльності [Електронний ресурс] / О. В. Торічний // Вісник Національной академії Державної прикордонної служби України, 2016 Bunycк 1 file:///C:/Users/Admin/Downloads/ Vnadped $2016 \quad 1 \quad 10 . p d f] 16 c$.

\section{REFERENCES}

1. Veretilnyk, V. V. (2017). Obgruntuvannia pedahohichnykh umov rozvytku viiskovo-spetsialnoi kompetentnosti ofitseriv-prykordonnykiv u protsesi mahisterskoi pidhotovky [Substantiation of pedagogical conditions of development of military-special competence of officers-border guards in the process of master's training]. Scientific Journal "ScienceRise: Pedagogical Education”, vol. 2 (10), pp. 46-50. [in Ukrainian].

2. Didenko, O. V. (2015). Profesiina kompetentnist ofitsera-prykordonnyka: sutnist poniattia [Professional competence of the border guard officer: the essence of the concept]. Osvitno-naukove zabezpechennia diialnosti pravookhoronnykh orhaniv $i$ viiskovykh formuvan Ukrainy: tezy VIII Vseukrainskoi naukovopraktychnoi konferentsii - Educational and scientific support of activity of law enforcement bodies and military formations of Ukraine: Abstracts of Papers VIII All-Ukrainian Scientific and Practical Conference. (pp. 263-264). Khmelnytsky:NASBGSU Publ. [in Ukrainian].

3. Lohinova, N. M. (2011). Formuvannia profesiinopravovoi kompetentnosti maibutnikh ofitseriv- 
prykordonnykiv [Formation of professional competence of future officers-border guards]. Extended abstract of candidate's thesis. National Academy of the State Border Guard Service of Ukraine named after Bohdan Khmelnytskyi, Khmelnytskyi, 20 p. [in Ukrainian].

4. Mashtaler, A. M. (2016). Rozvytok profesiinoi kompetentnosti ofitseriv-prykordonnykiv u systemi pidvyshchennia kvalifikatsii zasobamy dystantsiinoho navchannia [Development of professional competence of border guards officers in the system of professional development by means of distance learning]. Extended abstract of candidate's thesis. National Academy of the
State Border Guard Service of Ukraine named after Bohdan Khmelnytskyi, Khmelnytskyi, 16 p. [in Ukrainian].

5. Torichnyi, O. V. (2016). Formuvannia profesiinoi kompetentnosti maibutnikh ofitseriv-prykordonnykiv zasobamy proektnoi diialnosti [Formation of professional competence of future officers-border guards by means of project activity] [Electronic resource]. Bulletin of the National Academy of the State Border Guard Service of Ukraine, Vol. 1 file://C: /Users/ Admin/Downloads/Vnadped_2016_1_10.pdf], 16 p. [in Ukrainian].

Стаття надійшла до редакції 01.02.2018

УДК 001.12:37.013.32

Світлана Бабійчук, кандидат педагогічних наук Національний педагогічний університет імені М.П. Драгоманова, м. Киӥв

\section{НАУКОВА ОСВІТА ЯК ПЕДАГОГІЧНИЙ КОНЦЕПТ}

У статті розглянуто основні ідеї впровадження наукової освіти у шкільну практику. Представлено історію становлення наукової освіти на прикладі США та Великої Британії. Розглянуто тлумачення поняття “наукова освіта" закордонними та украӥнськими вченими. Висвітлено роль та місце наукової освіти у діяльності ЮНЕСКО. Базуючись на прачях професора Вінн Гарлен описано 10 принципів впровадження концепту наукової освіти в школі. Визначено, щэо метою впровадження наукової освіти в школі є навчити учня мислити як науковець та новатор.

Ключові слова: наукова освіта, учень, педагогічний концепт, педагогічний приниип, наукове дослідження.

Jim. 7.

Svitlana Babiychuk, Ph.D.(Pedagogy), National Mukhaylo Drahomanov Pedagogical University, Kyiv

\section{SCIENCE EDUCATION AS A PEDAGOGICAL CONCEPT}

The author considers the main ideas of introducing the science education into the school practice. The article reviewed the history of science education developing in the example of the United States of America and Great Britain. The explanation of the concept "science education" by foreign and Ukrainian scientists is considered. Science education should enhance learners' curiosity, wonder and questioning, building on their natural inclination to seek meaning and understanding of the world around. Science should be introduced and encountered by school students as an activity that is carried out by people including themselves. Their personal experiences of finding out and of making connections between the new and previous experiences not only bring excitement and personal satisfaction but also the realisation that they can add to their knowledge through active inquiry. Both the process and product of scientific activity can evoke a positive emotional response, which motivates further learning.

The role and place of science education of the UNESCO are highlighted. In a world that is increasingly shaped by science and technology, the UNESCO recognizes this and has made it its mission to not only spread education but to make an interest in the Sciences a prominent and lasting feature wherever it is offered.

Based on Professor Wynne Harlen's research, the author describes 10 principles of implementation of the concept of science education at school. It is determined that the purpose of the introduction of science education at school is to teach a pupil to act and think as a scientist and innovator. Undertaking scientific inquiry gives students the enjoyment of finding out for themselves and initiates appreciation of the nature of scientific activity, of the power and the limitations of science.

Keywords: science education, a pupil, pedagogical concept, a pedagogical principle, scientific research.

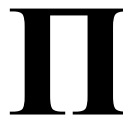

остановка проблеми у загальному вигляді та ії̈ зв'язок із важливими науковими чи практичними завданнями. Розвиток наукових знань направлений та виникає із потреби покращити умови існування людини. Наукові знання $є$ i

(C)

С. Бабійчук, 2018 результатом і засобом вивчення науки в школі. Історія вивчення науки у школі у таких економічно розвинених країнах, як США, Канада, Велика Британія, Швеція та ін., налічує більше 100 років. Закладені в школі основи наукового знання сприяють навчанню та вихованню нової генерації 